\title{
Cellulase and hemicellulase Activity under Submerged Fermentation of Rice Mill feed by Fungi
}

\author{
Ofongo, R.T.S..$^{1 *}$; Ohimain E.I. ${ }^{2}$; and E. A. Iyayi ${ }^{3}$ \\ ${ }^{1}$ Poultry Nutrition and Animal Biotechnology Research Group, Department of Animal Science, Niger Delta University, \\ Wilberforce Island, Bayelsa State Nigeria \\ Email: ruthofongo@gmail.com; tariruth@live.de \\ ${ }^{2}$ Veterinary Microbiology Research Unit, Department of Biological Sciences, Faculty of Science Niger Delta University, \\ Wilberforce Island, Bayelsa State, Nigeria. \\ Email: eohimain@yahoo.com \\ ${ }^{3}$ Department of Animal Science, Faculty of Agriculture, University of Ibadan, Oyo State - Nigeria. \\ Email: eaiyayi@yahoo.com
}

\begin{abstract}
Several agro-industrial by products are utilized in the synthesis of enzymes and production of other value-added products. This experiment was designed to access the cellulase and hemicellulase enzyme activity of three fungi (Aspergillus niger, Trichoderma viride and Rhizopus oryzae) in mono and mixed culture submerged fermentation using rice mill feed as substrate. The cellulase enzyme complex (cellulase (carboxy methyl cellulase, filter paper activity, $\beta$-glucosidase activity) and hemicellulase ( $\beta$-xylanase and $\beta$-xylosidase) were determined respectively.

Carboxy methyl cellulase activity was significantly improved by a mixed culture of all three fungi $(4.90 \mathrm{U} / \mathrm{ml})$ and a mixed culture of Trichoderma viride and Rhizopus oryzae $(4.83 \mathrm{U} / \mathrm{ml})$. There was no significant difference $(p>0.05)$ in concentration of carboxy methyl cellulase synthesized in mono culture submerged fermentation of rice mill feed but numerically high values were recorded with Trichoderma viride and Rhizopus oryzae. The activity of $\beta$-glucosidase was significantly $(p<0.05)$ high $(4.79 \mathrm{U} / \mathrm{ml})$ in mixed culture of the three fungi. Aspergillus niger and Rhizopus oryzae also yielded significantly $(p<0.05)$ high $\beta$-glucosidase activity of $3.00 \mathrm{U} / \mathrm{ml}$ and $2.13 \mathrm{U} / \mathrm{ml}$ respectively. The activity of $\beta$-xylanase was significantly $(p<0.05)$ enhanced $(3.77 \mathrm{U} / \mathrm{ml})$ with a mixed culture of all three fungi. Mono culture submerged fermentation resulted in significant $(p<0.05) \beta$-xylanase activity with Aspergillus niger $(1.83 \mathrm{U} / \mathrm{ml})$ and Rhizopus oryzae $(1.75 \mathrm{U} / \mathrm{ml})$ over Trichoderma viride $(1.26 \mathrm{U} / \mathrm{ml})$.

The fungi utilized in this study were able to produce cellulase and hemicellulase enzyme from rice mill feed in mono and mixed fungi fermentation. The enzyme activity of carboxy methyl cellulase, $\beta$-glucosidase and $\beta$ xylanase was noticeable.
\end{abstract}

Keywords- cellulase, enzyme activity, fungi, hemicellulase, rice mill feed.

\section{INTRODUCTION}

Rice mill feed is an agro-industrial by-product (AIB) from the one-step milling of rice. It has a high insoluble non-starch polysaccharide concentration of $576 \mathrm{~g} / \mathrm{kgDM}$, soluble non-starch polysaccharide concentration of $13 \mathrm{~g} / \mathrm{kgDM}$ and hemicellulose concentration of $211 \mathrm{~g} / \mathrm{kgDM}$ respectively [1]. It is a source of cellulosic waste that can be exploited for the production of value added products from unexploited cellulosic wastes [2] [3]. Cellulase plays a major role in the global enzyme market and is responsible for the hydrolysis of cellulose. It is composed of a complex mixture of enzyme proteins with different specifications to hydrolyze glycosidic bonds [4]. Cellulases are divided into three major enzyme activity classes [5]; [6]; [7]. These are endo-1, 4$\beta$-D-glucanase (E.C.3.2.1.4), exo-1, $4-\beta$-glucanase (exocellobiohydrolase or FPA activity, E. C. 3.2.1.91) and $\beta$ D-glucosidase (E.C.3.2.1.21). These enzymes together with other related enzymes viz hemicellulase and pectinases, are among the most important group of enzymes employed in the processing of lignocellulosic substrates into various desired products [4]. Xylans are the most abundant hemicellulose. Xylanase hydrolyze the $\beta-1,4$ bonds in the xylan backbone to yield short xylo-oligomers which are further hydrolyzed into single xylose units by $\beta$ - Xylosidase. Hemicellulose degradation of AIB is mediated through the action of xylanase and $\beta$-xylosidase. Complete hydrolysis of cellulose yields glucose while incomplete hydrolysis yields cello-oligomers (cellobiose). The production of 
cellulase by various microorganisms has been reported earlier ([8]; [9].

Crop residues, crop-processing wastes and sawdust come under agricultural cellulosic wastes previously viewed as valueless and considered for disposal only. The exploitation of cellulosic wastes as substrates has significant environmental, industrial and commercial outcomes. These waste materials can be utilized as raw materials for the production of potential value-added products such as enzymes (cellulase and hemicellulase) as pointed out in this study.

\section{MATERIALS AND METHODS}

\subsection{Experimental site and source of fungi}

Fungi utilized for the submerged fermentation of RMF were obtained from the culture bank of the Microbial Physiology Laboratory, Department of Botany and Microbiology, University of Ibadan. They were subcultured on Potato Dextrose Agar (PDA). The experiment was also carried out at the Botany and Microbiology Department of the University of Ibadan.

\subsection{Preparation of Inoculum}

A 1 x $6 \mathrm{~mm}$ cork borer of 7 days old culture of each fungus (Aspergillus niger, Trichoderma viride and Rhizopus oryzae) and was dispersed in $15 \mathrm{ml}$ sterile deionized water was prepared aseptically. A similar procedure was used to prepare inoculum of mixed culture of A. niger $+T$. viride; A. niger $+R$. oryzae; $T$. viride $+R$. oryzae and $A$. niger $+T$. viride $+R$. oryzae. $5 \mathrm{ml}$ of each inoculum was used to inoculate the sterile substrate.

\subsection{Determination of Inoculum size and Processing of} RMF samples

The inoculum used was prepared with a $1 \times 6$ cork borer of each fungus in (mono and mixed culture) from 7 days old culture plates dispersed in sterile deionized water. The inoculum size was determined using a hemocytometer to count the number of spores dispersed as reported by [10]. The RMF was in a ground form when collected from the rice mill and so did not require any further processing.

2.4 Determination of enzymes synthesized

A modified version of [11] medium as developed by [12] was used as basal medium to determine enzyme activity. Fifty (50) $\mathrm{ml}$ of the basal medium was added to $0.5 \mathrm{gm}$ of RMF in a $150 \mathrm{ml}$ Erlenmeyer flask. This was prepared in triplicates for each fungus and their mixed culture. Sterilization was carried out in an autoclave at $121^{\circ} \mathrm{C}$ for 15 mins and $15 \mathrm{psi}$. The flasks were inoculated with $3 \mathrm{ml}$ of inoculum individually. Inoculation was done after the flask had cooled. They were then incubated for 7 days at $30^{\circ} \mathrm{C} \pm 2^{\circ} \mathrm{C}$.

The basal medium contained per litre $\mathrm{KH}_{2} \mathrm{PO}_{4}$ (2.0gm); $\left(\mathrm{NH}_{4}\right)_{2} \mathrm{SO}_{4}(2.1 \mathrm{gm}) ; \mathrm{MgSO}_{4} .7 \mathrm{H}_{2} \mathrm{O}(0.3 \mathrm{gm}) ; \mathrm{CaCl}_{2} .6 \mathrm{H}_{2} \mathrm{O}$ (0.3gm); $\mathrm{MgSO}_{4} . \mathrm{H}_{2} \mathrm{O}$ (1.56mg); $\mathrm{ZnSO}_{4} .7 \mathrm{H}_{2} \mathrm{O}$ (1.4mg); $\mathrm{CoCl}_{2} .6 \mathrm{H}_{2} \mathrm{O}(2.66 \mathrm{mg})$; yeast extract $(0.5 \mathrm{gm})$ and was regulated to a $\mathrm{pH}$ of 5.0. During the incubation period, the flasks were placed on a rotary shaker at 80rpm for one hour daily. The contents of each flask were filtered through Whatman number 1 filter paper after 7 days and the filtrate taken as the crude enzyme. The filtrate without prior purification was used to determine the following enzymes: cellulase (carboxy methyl cellulase, filter paper activity, $\beta$-glucosidase activity) and hemicellulase ( $\beta$ xylanase and $\beta$-xylosidase) respectively. Filter paper activity (FPA) was taken as a measure of cellobiohydrolase which a component of cellulase enzyme complex. The activity of $\beta$-glucosidase activity was determined using $P$ - nitrophenyl $-\beta-D$-glucoside (PNPG) as substrate. Enzyme activity was specified as unit per $\mathrm{ml}(\mathrm{U} / \mathrm{ml})$ of crude enzyme filtrate. Cellulose activity against filter paper and carboxymethyl cellulase (CMCase) was measured as described by [13]. The $\beta$ glucosidase activity was determined by using $P$ nitrophenyl- $\beta$ - $D$-glucoside (PNPG) as substrate [14]. Xylanase: according to the method of [15] and $\beta$ xylosidase also according to the method of [15].

\subsection{Experimental design and statistical analysis}

Completely randomized design was used for the experiment having seven treatments and three replicates per treatment. Data obtained were subjected to one-way Analysis of Variance (ANOVA) and significant means separated by Duncan Multiple Range Test using SPSS version 17 (SPSS Inc, Chicago, USA).

\section{RESULTS AND DISCUSSION}

Results obtained from the hydrolysis of rice mill feed with A. niger, $T$. viride and $R$. oryzae in mono and mixed culture submerged fermentation indicated that RMF is a suitable substrate for the synthesis of cellulase and hemicellulase enzyme.

\subsection{Cellulase activity in mono and mixed culture} submerged fermentation of rice mill feed

Mono-culture submerged fermentation $(\mathrm{SmF})$ of rice mill feed with $A$. niger, $T$. viride and $R$. oryzae resulted in varied enzyme activity of cellulase complex (fig. 1). Rhizopus oryzae produced numerically higher CMCase activity $(4.63 \mathrm{U} / \mathrm{ml})$ over $T$. viride $(4.60 \mathrm{U} / \mathrm{ml})$ and $A$. niger $(3.97 \mathrm{U} / \mathrm{ml})$. These values were however not significantly different from one another $(p>0.05)$. The value of FPA recorded followed a similar trend with values ranging from $2.63 \mathrm{U} / \mathrm{ml}$ (A. niger) to $2.87 \mathrm{U} / \mathrm{ml}$ with $T$. viride respectively. Significantly higher $(p<0.05) \beta$-glucosidase activity of $3.00 \mathrm{U} / \mathrm{ml}$ was recorded with $A$. niger in monoculture submerged fermentation. The activity of this enzyme was significantly $(p<0.05)$ low $(1.82 \mathrm{U} / \mathrm{ml})$ with $T$. viride compared to a value of $2.13 \mathrm{U} / \mathrm{ml}$ with $R$. oryzae. The cellulase complex enzyme activity in mixed -culture submerged fermentation of rice mill feed is presented in 
fig. 2. Unlike mono-culture SmF, a mixed culture of all three fungi resulted in significantly higher $(p<0.05)$ CMCase activity of $4.90 \mathrm{U} / \mathrm{ml}$ which was followed by a value of $4.83 \mathrm{U} / \mathrm{ml}$ in a mixed-culture of $T$. viride and $R$. oryzae. The least value of $3.03 \mathrm{U} / \mathrm{ml}$ was recorded when $A$. niger and T. viride were co-cultured. There was no significant different $(p>0.05)$ in FPA in mixed-culture of any combination of the three fungi. On the other hand, $\beta$ glucosidase activity was significantly $(p<0.05)$ high with a mixed culture of all three fungi yielding an enzyme activity of $4.79 \mathrm{U} / \mathrm{ml}$. this was followed by a value of $3.31 \mathrm{U} / \mathrm{ml}$ with $A$. niger $+R$. oryzae mixed -culture, $2.65 \mathrm{U} / \mathrm{ml}$ (T. viride $+R$. oryzae) and $2.46 \mathrm{U} / \mathrm{ml}$ with $A$. niger $+T$. viride.

Cellulose has been reported to be the best inducer of fungal cellulase [16]. Cellulose degradation however, depends on the synergistic action of different components of cellulase enzyme and the induction of synthesis of individual components of the enzyme system is different in different fungi $[17 ; 18]$. Endoglucanase (CMCase) or endo-1, 4- $\beta$ - $D$-glucanase are proposed to initiate attack randomly at multiple internal sites in the amorphous region of cellulose fibre opening-up sites for subsequent attack by cellobiohydrolase (exo-1, $4-\beta$-glucanase) as reported by [19]. Cellobiohydrolase (FPA activity) is involved in the removal of mono and dimmers from the end of the cellobiose chain. The activity of $\beta$-glucosidase hydrolyses glucose dimmers and in some cases cellooligosaccharides to glucose. Endoglucanase and cellobiohydrolase work synergistically in the hydrolysis of cellulose, but the details of the mechanism involved were reported to be unclear [7]. Endoglucanase is the major component of fungal cellulase complex accounting for $40-70 \%$ of the total cellulase proteins and can hydrolyze highly crystalline cellulose [20]. However, a low FPA activity would mean less substrate for $\beta$ glucosidase to hydrolyze to glucose and a possible substrate induced feed-back inhibition of the cellulase complex. Variations in the CMCase (endoglucanase) and FPA (exo-glucanase) activity recorded in this study may be as a result of multiple distinct variants of these enzymes exhibited by the fungi utilized [21;22].

An earlier report by [23] identified paddy husk as the best source for maximum enzyme production (endo and exo$\beta$ - 1, 4-D-glucanases) by Hypocrea nigricans among different lignocellulosic substrates screened. Paddy husk enzyme yield was reported to be maximum under optimal cultural conditions at $\mathrm{pH} 6.0$, incubation temperature $30^{\circ} \mathrm{C}$, moisture content $40 \%$, and spore density of $2 \times 10^{6}$ spores/g of substrate under solid state fermentation conditions. Maximum cellulase production using alkalitreated soybean hulls was found to yield CMCase, FPase and $\beta$-glucosidase activities of $9.91 \pm 0.04,6.20 \pm 0.13$ and $5.69 \pm 0.29 \mathrm{U} / \mathrm{g}$, respectively [24]. According to [25],
Maximum lignocellulolytic enzyme activities were obtained on day 6 of cultivation. The authors reported a value of $6.0 \mathrm{U} / \mathrm{mL}$ for CMCase activity and $14.5 \mathrm{U} / \mathrm{mL}$ for xylanase activity respectively under solid state fermentation conditions. Values recorded for both enzymes under submerged state fermentation in this study were lower compared to the authors report [25]. Notwithstanding this, other published work has also indicated this fact [26]. According to [26], A. niger KKS produced FPase, CMCase, $\beta$-glucosidase, xylanase and $\beta$ xylosidase activity considerably in submerged fermentation. A mutant version of the same fungi was later reported by $[27 ; 28]$ to produce relatively higher activity of $\beta$-glucosidase (514iu/g of ground rice straw in Submerged fermentation and produced xylanase activity higher than 5000iu/g of rice straw under solid state fermentation. Earlier reports have indicated the possibility of inoculum size playing a role in enzyme activity recorded $[29 ; 23 ; 30 ; 31]$.

\subsection{Hemicellulose activity in mono culture submerged fermentation of RMF}

Hemicellulase enzyme activity in mono and mixed fungi submerged fermentation of rice mill feed is presented in fig 3 and fig 4 respectively. The enzyme activity of $\beta$ xylanase was significantly high $(p<0.05)$ with $\mathrm{A}$. niger $(1.83 \mathrm{U} / \mathrm{ml})$ and $R$. oryzae $(1.75 \mathrm{U} / \mathrm{ml})$ mono-culture submerged fermentation of rice mill feed than $T$. viride $(1.26 \mathrm{U} / \mathrm{ml})$. Conversely, the activity of $\beta$-xylosidase was not observed to be significantly different $(p>0.05)$ across mono-culture submerged fermentation with A. niger, $T$. viride and $R$. oryzae respectively. Nevertheless, the value recorded with $R$. oryzae was numerically higher $(2.28 \mathrm{U} / \mathrm{ml})$ than that recorded for A. niger $(2.05 \mathrm{U} / \mathrm{ml})$ and T. viride $(2.21 \mathrm{U} / \mathrm{ml})$ respectively.

Mixed -culture submerged fermentation of rice mill feed with $A$. niger $+T$. viride $+R$. oryzae resulted in significantly higher $(p<0.05) \quad \beta$-xylanase activity of $3.77 \mathrm{U} / \mathrm{ml}$ over a combination of $A$. niger $+R$. oryzae, $A$. niger $+T$. viride and $T$. viride $+R$. oryzae. The least value of $2.47 \mathrm{U} / \mathrm{ml}$ was recorded with $T$. viride and $+R$. oryzae. Then again, enzyme activity of $\beta$ - xylosidase ranged between $2.17 \mathrm{U} / \mathrm{ml}$ with $A$. niger $+R$. oryzae to $2.78 \mathrm{U} / \mathrm{ml}$ with a mixed culture of $A$. niger $+T$. viride + $R$. oryzae. However, there was no significant difference $(p>0.05)$ in enzyme activity of $\beta$ - xylosidase during mixed fungi submerged fermentation of rice mill feed.

Xylans are hydrolyzed by five enzymes: endo-1, 4- $\beta$ xylanase (E. C. 3.2.1.8), $\beta$-xylosidase (E. C.3.2.1.37), $\alpha$ L-arabino-furanosidase (E. C. 3.2.1.55), acetyl esterase (E. C. 3.1.1.6) and $\alpha$-glucuronidase (E. C. 3.2.1.139) as reported by [32]. Of which only two, $\beta$-xylanase and $\beta$ xylosidase activities were considered in the current study (fig. 3 and fig. 4 below). $\beta$-xylosidase activity was 
observed to be high in A. niger, T. viride and R. oryzae mono cultures compared to their mixed culture treatments. The $\beta$-xylanase and $\beta$-xylosidase activities reported in this study may likely be related to the hemicellulose content of rice husk (205g/kgDM) [33] compared to a high cellulase activity with a corresponding high cellulose content $(338 \mathrm{~g} / \mathrm{kgDM})$. The presence of such a multifunctional xylanolytic enzyme system is found to be quite common among fungi, actinomycetes, and bacteria [34]. The results of this study not only highlight the potential of rice mill feed as a good substrate for the production of cellulase and hemicellulase enzyme but further buttressed the role the nature of a substrate in its hydrolysis by different fungi [36]. Production of cellulase and hemicellulase has been shown to be affected by the nature of the substrate used in fermentation [35]. Cellulase and hemicellulase enzyme activity can differ from enzyme to enzyme according to substrate composition [35]. According to earlier reports [37], Fuscoporia gilva and Pleurotus tuberregium produced high amount of laccase (440.86 U/L and $480.63 \mathrm{U} / \mathrm{L}$ at day 7 ), as well as carboxymethyl cellulase (CMCase) $(4.78 \mathrm{U} / \mathrm{mL}$ at day 21 and $3.13 \mathrm{U} / \mathrm{mL}$ at day 14$)$ and xylanase $(4.48 \mathrm{U} / \mathrm{mL}$ and $7.8 \mathrm{U} / \mathrm{mL}$ at day 21 ), respectively. In addition, besides the fact that enzyme yields from solid state fermentation is more over submerged fermentation process other reports indicated that the period of solid state fermentation may also play a role in enzyme yields for CMCase and xylanase, [37].

\section{CONCLUSION}

Agro-industrial by-products obtained from rice farming can be quite enormous in rice growing communities and countries. Excess waste can be an issue of concern to such communities. Evidently, rice mill feed has potential as a suitable substrate for the synthesis of cellulase and hemicellulase enzyme under submerged fermentation with fungi. The enzyme activity of CMCase and $\beta$ glucosidase was very noticeable in this study.

\section{ACKNOWLEDGEMENTS}

The authors gratefully acknowledge the following personnel (Mr Fadobga, Mr Peter, Mrs Mpkama) of the Botany and Microbiology Laboratory, University of Ibadan. The authors wish to thank Sylvester Izah for the editorial work.

\section{REFERENCES}

[1] Ofongo, S.T., Kehraus, S., Iyayi, E.A. and Südekum, K. H. (2008). Rice Mill Feed: an Agroindustrial By-product with Potential for Rural Development. In: Proceedings of Tropentag (Conference on International Research on Food
Security, Natural Resources Management and Rural Development) University of Hohenheim, StuttgartGermany. $7^{\text {th }}-9^{\text {th }}$ October, 2008. Pp 439

[2] Bala Kumaran, M.D. Kalaichelvan, P.T. and Santhi R. (2015). Exploitation of Agro-Industrial Wastes as Substrates for Cellulase Production by Bacillus licheniformis MTCC 429. Microbiology Journal 5 (2): 36-42. DOI: $10.3923 / \mathrm{mj} .2015 .36 .42$

[3] Hao, X.C., Yu X.B. and Yan, Z.L. (2006). Optimization of the medium for the production of cellulase by the mutant Trichoderma reesei $\mathrm{WX}-112$ using response surface methodology. Food Technol. Biotechnol. 44: 89-94. https://hrcak.srce.hr/109766

[4] Howard, R. L., Abotsi, E., Jansen van Rensburg, E. L. and Howard, S. (2003). Lignocellulose biotechnology: issues of bioconversion and enzyme production. African Journal of Biotechnology Vol 2 (12), pp. 602-619. http://www.academicjournals.org/AJB

[5] Goyal, A.; Ghosh, B.; Eveleigh, D. (1991). Characterization of fungal cellulase. Biores Technol. 36: 37-50.

[6] Rabinovich, M.L.; Melnik, M.S.; Bolobova, A.V. (2002a) Microbial cellulases: A review. Appl. Biochem. Microbiol. 38 (4): 305-322. https://doi.org/10.1023/A:1016264219885

[7] Rabinovich, M.L.; Melnik, M.S.; Bolobova, A.V. (2002b). The structure and mechanism of action of cellulolytic enzymes. Biochemistry (Moscow) 67 (8): 850-871. https://doi.org/10.1023/A:1019958419032

[8] Shamala, T.R. and Sreekantiah, K.R. (1986). Production of cellulases and D-xylanase by some selected fungal isolates. Enzyme Microb. Technol. 8: 178-182. https://doi.org/10.1016/01410229(86)90109-2

[9] Muniswaran, P.K.A. and Charyulu, N.C.L.N. (1994). Solid substrate fermentation of coconut coir pith for cellulase production. Enzyme Microb. Technol. 16(5): 436-440. https://doi.org/10.1016/0141-0229(94)90161-9

[10] Ofongo, R.T.S.; Ohimain, E.I.; and Iyayi E. A. (2018). Enzyme activities during submerged fermentation of rice mill feed by Aspergillus niger, Trichoderma viride and Rhizopus oryzae. International Journal of Agriculture and Environmental Research. Volume:04 (6):1383 1392.

[11] Mandel, M. and Weber, J. (1969). The production of cellulases in: Cellulases and its application, Advances in Chemistry Series, Gould, R.F. eds., American Chemical Society, Washington, DC, 95(1): 391-414.

[12]Hatakka, A. I. and Pirhonen, T. I, (1985). 
Cultivation of wood rotting fungi on agricultural lignocellulosic materials for production of crude protein. Agricultural wastes 12, $81 \quad$ - 97. https://doi.org/10.1016/0141-4607(85)90001-0

[13] Mandels, M., Andreotti, R. and Roche, C. (1976). Measurement of saccharifying cellulase. Biotechnology and Bioengineering Symposium No. 6, 21-23.

[14] Mandels, M., Hortz, L. and Nystron, J. 1974. Enzymatic hydrolysis of waste cellulose. Biotchnol. Bioeng. 16:1471-1493. https://doi.org/10.1002/bit.260161105

[15] Berridge, N. J. (1955): In Methods in Enzymology, Vol. 1, (Eds. S. P. Colowick and N. O. Kaplan), Academic Press, London.

[16] Bastawde, K.S. 1992: Cellulolytic enzymes of thermotolerant Aspergillus terreus strain and their action on cellulosic substrates. World Journal of Microbiology and Biotechnology 8, 45-49.

[17] Steinberg, D. 1976: $\beta$-glucosidase of Trichoderma: its biosynthesis and role in saccharification of cellulose. Appl. Environ. Microbiol. 31. 648-654.

[18] Garg, S.K. and Neelkantan, S. 1982: Effect of nutritional factors on cellulase enzyme and microbial protein production by Aspergillus terreus and its evaluation. Biotechnology and Bioengineering 24, 109-125.

[19] Wood, T.M. (1991). Fungal Cellulase. In Haigler et al (eds) Biosynthesis and Biodegradation of cellulose. Macel Dekker Inc. New York. Pp 491534.

[20] Esterbauer, H.; Steiner, W.; Labudova, L.; Hermann, A. and Hayn, M. (1991). Production of Trichoderma cellulase in laboratory and pilot scale. Bioresource Technol. 36(1): 51-65. https://doi.org/10.1016/0960-8524(91)90099-6

[21]Beldman, G.; Voragen, A. G. J.; Rombouts, and Pilnik, W. (1988). Synergism in cellulose hydrolysis by endoglucanases and exoglucanases purified from Trichoderma viride. Biotechnology and bioengineering, volume 31 (2): Pages 173-178. https://doi.org/10.1002/bit.260310211

[22] Shen, H.; Gilkes, N.R.; kilbum, D.G. (1995). Cellobiohydrolases $\mathrm{B}$, a second exocellobiohydrolase from the cellulolytic bacterium Cellulomonas fimi. Biochem. J. 311: 67-74. DOI: 10.1042/bj3110067

[23] Myla, S. K., Parapatla, H. R., Mekala,C. D., Kasireddy, H. R. (2016). Production of Endo-1,4- $\beta$ $D$-Glucanase and Exo-1,4- $\beta$ - $D$-Glucanase on cellulosic substrates in solid state fermentation by Hypocrea nigricans. International Journal of Advanced Research. Volume 4, Issue 5, 288-299. DOI: $10.21474 /$ IJAR01
[24] Salihu, A., Abbas, O., Sallau, A. B., and Alam, Md. Z. (2015). Agricultural residues for cellulolytic enzyme production by Aspergillus niger: effects of pretreatment. 3 Biotech. 5:1101-1106. DOI 10.1007/s13205-015-0294-5

[25] Isikhuemhen, S. O., Mikiashvili, N. A., Adenipekun, C. O., Ohimain, E. I. and Shahbazi, G. 2012. The tropical white rot fungus, Lentinus squarrosulus Mont.: Lignocellulolytic enzymes activities and sugar release from cornstalks under solid state fermentation. World Journal of Microbiology and Biotechnology. $28 \quad$ (5): $\quad$ 1961-1966. DOI:10.1007/s11274-011-0998-6

[26] Kim, S.W., Kang, S.W. and Lee, J.S. (1997). Cellulase and xylanase production by Aspergillus niger KKS in various bioreactors. Bioresource Technology. $\quad 59(1): \quad 63 \quad-\quad 67$. https://doi.org/10.1016/50960-8524(96)00127-7

[27] Kang, S.W., ko, E.H., Lee, J.S. and Kim, S.W. (1999). Over production of $\beta$-glucosidase by Aspergillus niger mutant from lignocellulose biomass. Biotechnol. Let. 21: $647-650$.

[28]Park, Y.S., Kang, S.W., Lee, J.S., Hong, S. I. and Kim, S. W. (2002). Xylanase production in solid state fermentation by Aspergillus niger mutant using statistical experiment designs. Applied microbiology biotechnology. $\quad 58: 761 \quad$ - $\quad 766$. https://doi.org/10.1007/s00253-002-0965-0

[29] Ofongo, R.T.S., Ohimain, E.I. and Iyayi E. A (2018). Enzyme activities during submerged fermentation of rice mill feed by Aspergillus niger, Trichoderma viride and Rhizopus oryzae. International Journal of Agriculture and Environmental Research. 4(6):1383 - 1392.

[30]Zambare, V. 2010. Solid state fermentation of Aspergillus oryzae for Glucoamylase production on agro residues. International Journal of Life Science. 4: $16-25$.

[31] Kunamneni, A., Permaul, K. and Singh, S. 2005. Amylase production in solid state fermentation by the thermophilic fungus Thermomyces lanuginosus. Journal of Bioscience and Bioengineering. 100:16817. DOI:10.1263/jbb.100.168

[32] Srinivasan, M.C. and Rele, M.V. (1999). Microbial xylanases for paper industry. Current science. 77:137-142. https://www.jstor.org/stable/24102921

[33]Pandey, P. and Pandey, A.K. (2002). Production of cellulase-free thermostable Xylanase by an isolated strain of Aspergillus niger PPI, utilizing various lignocellulosic wastes. World Journal of Microbiology and Biotechnology, 18: 281-283. https://doi.org/10.1023/A:1014999728406

[34]Bajpai, P. (2014). Microbial Xylanolytic Systems and Their Properties. In: Xylanolytic enzymes. 
Academic Press. Pp. 19 - 36. https://doi.org/10.1016/B978-0-12-801020-4.000032

[35] Kang, S.W., Park, Y.S., Lee, J.S., Hong, S.I. and Kim, S.W. (2004). Production of cellulases and hemicellulase by Aspergillus niger KKS from lignocellulosic biomass. Bioresource technology. 91: 153 - 156. doi:10.1016/S0960-8524(03)00172$\mathrm{X}$

[36] Ogwuche, V. A., Chilaka, F. C., Eze, S. O. O. and Anyanwu, C. U. (2012). Production and properties 5

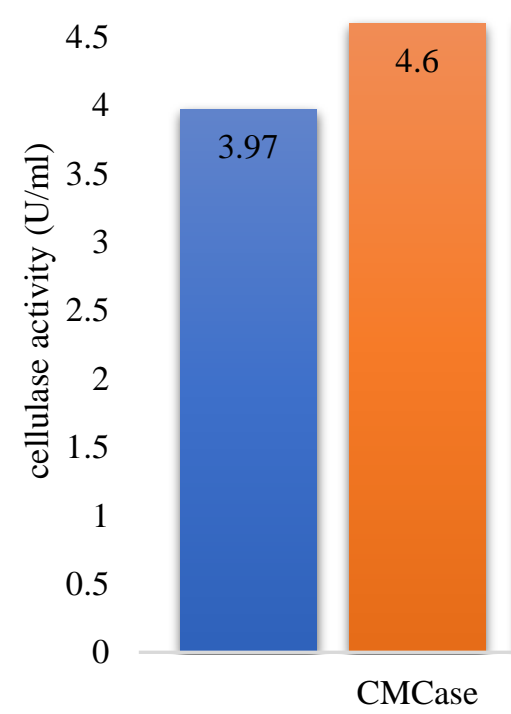

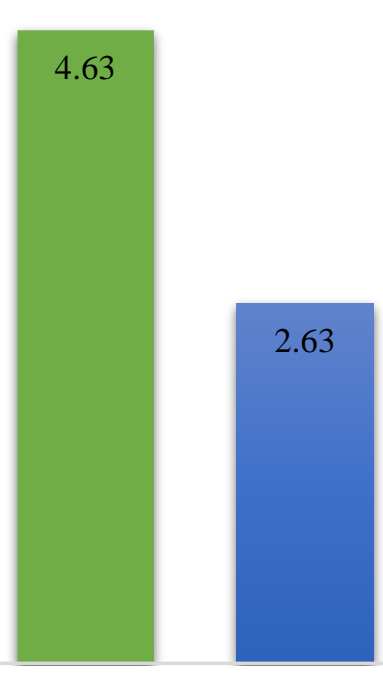

Fig.1: cellulase activity in mono culture submerged fermentation of rice mill feed of fungal cellulase from native isolates using orange bagasse as carbon source. Plant Product Research Journal. Volume 16: $16-22$.

[37] Isikhuemhen, O. S., Mikiashvili, N. A., Senwo, Z. N. and Ohimain, E. I. 2014. Biodegradation and Sugar Release from Canola Plant Biomass by Selected White Rot Fungi. Advances in Biological Chemistry. $\quad 4$ 395-406. DOI: $10.4236 / \mathrm{abc} .2014 .46045$

\section{- Aspergillus niger \\ Trichoderma viride \\ Rhizopus oryzae}
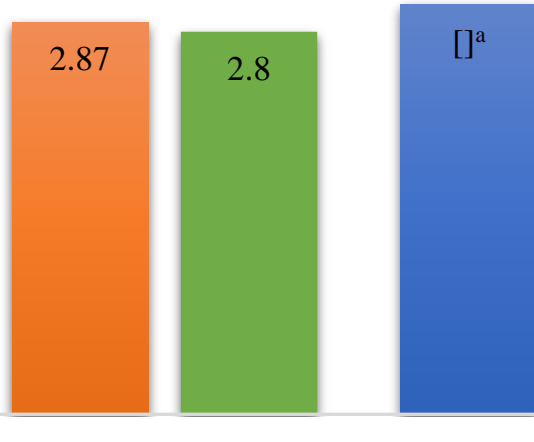

[]$^{b}$

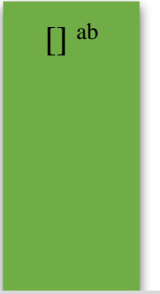

Beta glucosidase

FPA

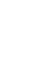

6

A. niger $+R$. oryzae $\square$ A. niger $+T$. viride $\square T$. viride $+R$. oryzae $\backsim A$. niger $+T$. viride $+R$. oryzae

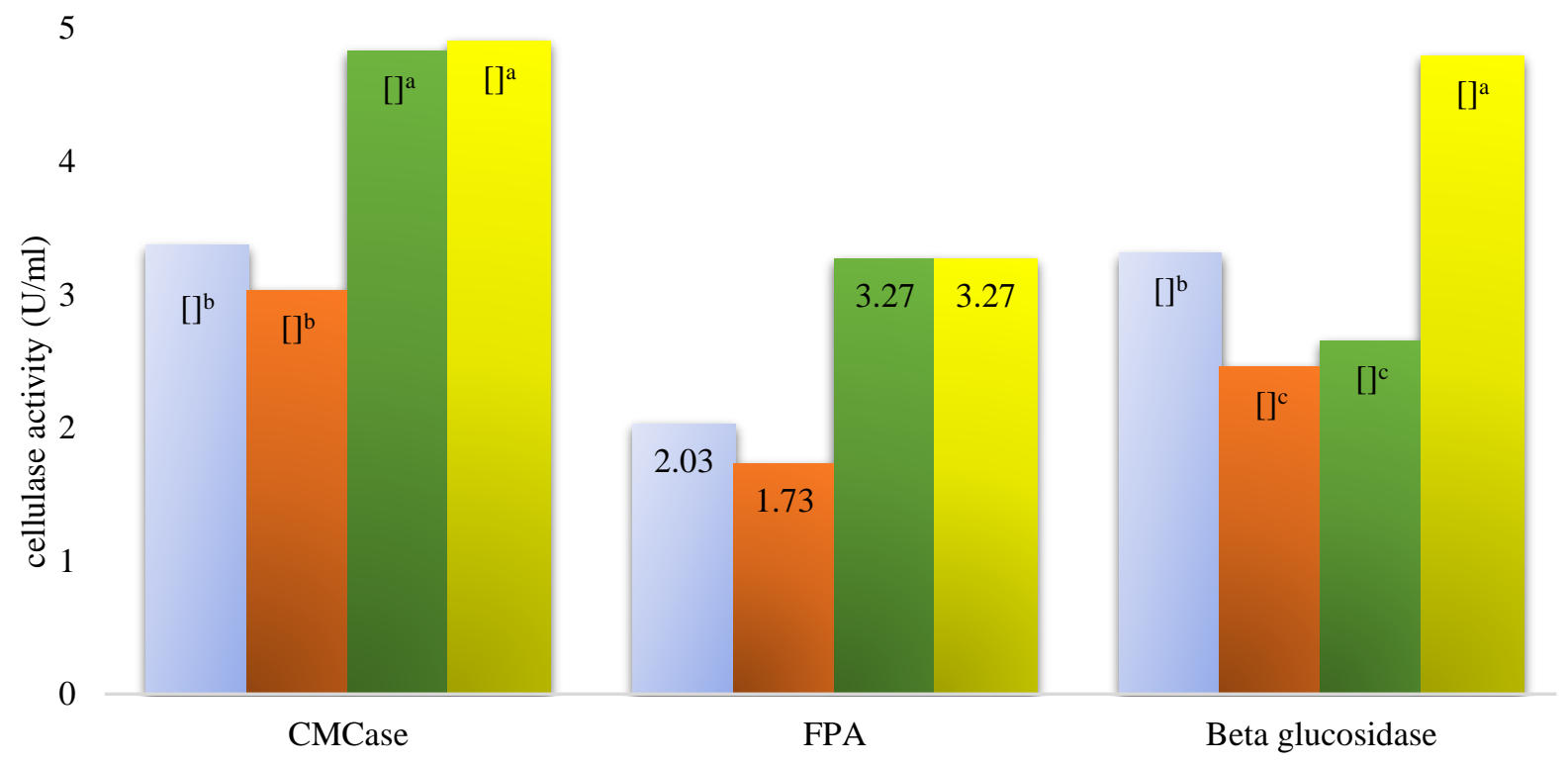

Fig.2: cellulase enzyme complex during mixed submerged fermentation of rice mill feed 
2

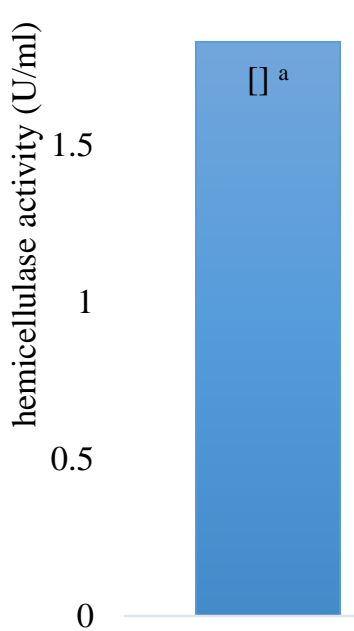

Beta-xylanase

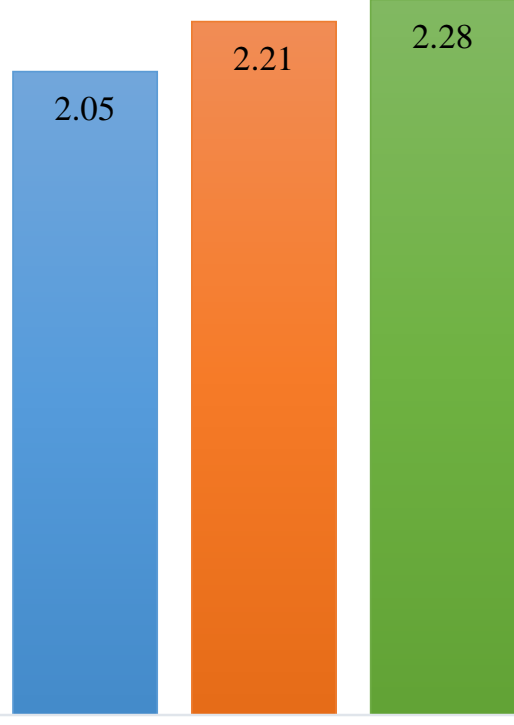

Beta-xylosidase

Fig.3: hemicellulase enzyme activity in mono culture submerged fermentation of rice mill feed

$$
\square \mathrm{ASP}+\mathrm{RHI} \quad \square \mathrm{ASP}+\mathrm{TRI} \quad \square \mathrm{TRI}+\mathrm{RHI} \quad \square \mathrm{ASP}+\mathrm{TRI}+\mathrm{RHI}
$$

4

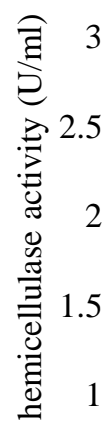

0.5

0

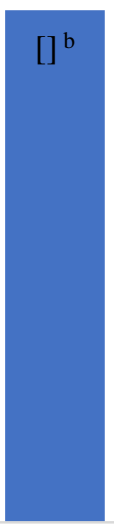

Beta-xylanase

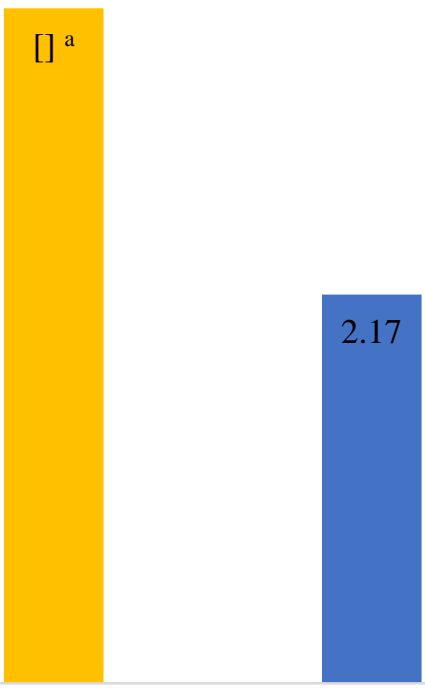

Beta xylosidase

Fig.4: hemicellulase enzyme activity during mixed fungi culture submerged fermentation of rice mill feed 